\title{
An Analysis of the Problems and Countermeasures in the Management of Students of Sino-foreign Cooperative Education of Chinese Universities*
}

\author{
Hao Feng \\ School of Humanities and Law \\ Northeastern University \\ Shenyang, China 110819 \\ School of Humanities and Law \\ Shenyang University \\ Shenyang, China 110044
}

\author{
Yang Li \\ School of Humanities and Law \\ Shenyang University \\ Shenyang, China 110044
}

\begin{abstract}
Sino-foreign cooperative education is an important channel for cultivating high-quality international talents. Since its appearance in Chinese education field, it has been continuously developed and improved. It has gradually become a new form of cooperation and exchange with foreign countries of Chinese education, become the new way of cultivating highquality talents, and become an important part of China's education. On the whole, there are still many problems in the current student management work of Sino-foreign cooperative education. This requires us to conduct in-depth research on student management, actively find solutions to these problems, and continuously improve the student management level of colleges and universities.
\end{abstract}

Keywords-Sino-foreign cooperative education; student management; solutions to problems

\section{THE NECESSITY OF STUDYING THE STUDENT} MANAGEMENT WORK IN SINO-FOREIGN COOPERATIVE EDUCATION OF CHINESE UNIVERSITIES

\section{A. Ideological and Political Work Faces New Challenges}

There are considerable differences in the educational concept, management model, and school system between universities at home and abroad. What's more, universities at home and abroad also differ greatly in politics, economy, culture, and values. College students' ideas are more open and more active, and are more likely to be influenced by foreign ideas. This makes students more likely to have ideological and political ambiguities and deviations, has brought great trouble to the ideological and political management for students, and is an unavoidable problem in student management[1].

*Fund Project: Research Results of the 2017 Party Building Project of Liaoning Higher Education Institution "Research on the Countermeasures for Students' Party Building Work in Colleges' Sino-foreign Cooperative Education in the Context of New Media" (2017GXDJ-B149), project leader Hao Feng..

\section{B. Students Have Excellent Family Conditions, Little Self- discipline, and Little Learning Enthusiasm, Making It Difficult to Manage Them}

Most of the students in colleges that conduct Sino-foreign cooperative education have good family conditions. And most of them are the only children in their families. They have grown up under the care of their parents and relatives. Parents will meet all their requirements. Some students have lived like princes or princesses since their childhoods. They lack the selfcare ability and self-discipline. They go their own ways, are extremely sloppy, and generally lack the spirit of struggle and independence, which leads to their not having the awareness of self-learning. Therefore, they have little enthusiasm for learning, and there are many students who have abandoned their studies because they cannot withstand the tremendous learning pressure.

\section{Students Have Much Pressure in English Learning, and Ignore Campus Activities}

It can be seen from the literal meaning of "Sino-foreign cooperative education" that this mode of education will have very high requirements for students' English level. This is indeed the case. It was proposed in the teaching plan negotiated by both Chinese and foreign universities that students should pass the English proficiency test with a certain level during their studies in China. Otherwise, they will not be allowed to continue the study in Sino-foreign cooperative education and will be eliminated. For students and their parents, this is undoubtedly a cruel reality and a considerable challenge. In addition, professional courses in Sino-foreign cooperative education are mostly taught by foreign teachers. When students study abroad, they are taught completely in English and have to communicate with foreigners in English in the daily life. These situations require students to have excellent English application abilities, which is a big challenge for most students. Due to the heavy burden of English learning, students spend most of their time and energy in learning English, which leads to their ignoring the campus cultural 
activities. In fact, it is not that they do not want to participate, but the reality does not allow them to spend too much time on these extra-curricular activities. This leads to their lack of campus cultural life, which also causes that their overall quality is far worse than that of students in other departments.

\section{THE PROBLEMS EXISTING IN THE MANAGEMENT OF} STUDENTS OF THE SINO-FOREIGN COOPERATIVE EDUCATION IN CHINESE UNIVERSITIES

\section{A. There Is a Lack of Guidance of Theories and Practical Experience in Student Management}

Sino-foreign cooperative education is a brand-new mode of education. The student management system is not perfect enough and mature enough. There are almost no successful cases in China that can be referenced. Most Sino-foreign cooperative education institutions can only apply the student management model of ordinary universities. However, the lack of pertinence, that is, not combining the characteristics of Sino-foreign cooperative education and its students to formulate the corresponding model, leads to the not obvious effect[2].

\section{B. The Quality of Student Management Workers Does not Meet the Required Standards}

The Sino-foreign cooperative education program aims to cultivate high-quality international talents for the society. This puts high requirements on student administrators. They must do a good job in all aspects of student management, including students' learning, life, interpersonal communication, etc. This requires that administrators not only have professional competence, knowledge and skills, but also have sufficient knowledge about Sino-foreign cooperative education, correct and clear ideological and political awareness, and the ability to well communicate with students. However, the actual situation is that most of the student managers of Sino-foreign cooperative education do not meet this standard.

\section{Colleges and Universities Neglect Student Management}

The students who choose Sino-foreign cooperative education and their parents are only concerned about whether these institutions can make students get good grades in English and other majors, so that students can successfully obtain visas to study abroad. In order to cater to students and parents' needs, and in order to improve their position among similar institutions, most institutions often only make effort in improving the students' English proficiency and helping students obtain visas to go abroad. Colleges and universities' thinking about problems is not comprehensive. They have utilitarian intentions, often neglect the management of students, and lack the awareness of management model innovation, causing that there is a big loophole in student management of schools, affecting the quality and reputation of cooperative education projects, and thus affecting their sustainable development. There is a lack of competitiveness among institutions, many institutions even fail to recruit one student, and the interests of countries, schools, teachers, students, families, etc. have been damaged.

\section{CONCLUSION}

The countermeasures for the problems in the management of students in Sino-foreign cooperative education in Chinese universities are as follows.

\section{A. Strengthen the Ideological and Political Education for College Students}

The ideological and political education for students is always the core content in student management. Colleges and universities should try their best to carry out a variety of activities for students and provide them with enough practical opportunities[3], so that they can receive real and concrete education in social practice, rather than just read books in classrooms. Teachers should guide students to establish correct outlook on world, life, and value in practical activities so that they will be more willing to accept ideological and political education. Schools should pay more attention to the training of full-time instructors for Sino-foreign cooperative education. This can effectively promote the development of the ideological and political education for students. Instructors should have broad international perspectives and good ideological and political qualities, be able to face up to the differences between different ideological and political cultures, have good skills in communicating and interacting with students, and be able to carry out various kinds of activities that can both cultivate students' ideology and politics and be popular among students.

\section{B. Strengthen the Construction of the Learning Atmosphere, Attach Importance to Psychological Counseling, and \\ Promote Students to Make Progresses}

Sino-foreign cooperative colleges and universities should pay attention to the construction of good learning atmosphere, establish students' awareness of discipline, and correct their learning attitude. On the one hand, it is necessary to formulate strict disciplines and regulations, and violations such as school absenteeism and fights must be punished, serious violations should be disciplined. Gradually, students' sense of discipline should be established and good campus atmosphere should be formed. On the other hand, schools should take measures to create a good learning atmosphere for students and strengthen the construction of the campus atmosphere[4]. For example, select advanced students, model students, etc. It can motivate students and stimulate their enthusiasm for learning so that more students will learn and progress together. It can be encouraged that the award-winning students share their experience and communicate with other students. Other students can follow the award-winning students as models, continuously improve themselves, and work hard to become the next award-winning student. It is also necessary to encourage students to form moderate sense of competition and to be positive and progressive.

\section{Carry out Various Extra-curricular Activities to Guide Students to "Learn in Entertainment" and Improve Their Comprehensive Qualities}

Sino-foreign cooperative education colleges and universities should attach great importance to cultivating the comprehensive quality of students and encourage students to 
learn in "doing", in "playing", and in "having fun", but not to completely confine themselves to rigid learning modes. Schools should encourage students to actively participate in campus cultural activities, social practice activities, voluntary service activities, and a variety of amateur cultural activities, such as song and dance parties, talent competitions, Chinese and foreign student debate competitions, class cultural demonstrations, communication parties, etc. Schools can integrate English learning into various activities. For example, Chinese and foreign students can jointly participate in the activities. Through the cooperation and exchanges with foreign students, Chinese students can not only improve their English level and relieve their English learning pressure, but also enhance their ability to adapt to the environment and practical ability. Through participating in the colorful cultural activities, students can improve their comprehensive abilities, cultivate their moral sentiments, and develop their physical and mental health. This will make the student management work go smoothly.

\section{D. "Family-school Cooperation", Two-pronged Approach}

The students of Sino-foreign cooperative education are facing many problems. The most obvious problem is the adaptation to the new model of teaching. The education model with the "elimination mechanism" and the high requirements for English level have made students have heavy psychological burden and feel anxious. Only relying on the management of schools and self-adjustment of students cannot completely solve these problems. To completely solve the problems requires the participation of families. So a new student management model of "family-school cooperation" can be established.

Schools should first introduce the teaching model and concept of Sino-foreign cooperative education and the differences between the teaching system of Sino-foreign cooperative universities and that of ordinary universities to students' parents. The above can be introduced at parents' meetings and in parental WeChat groups so that parents can have a comprehensive and correct understanding of Sinoforeign cooperative education. Schools should enable them to understand and accept the fact that the elimination rate of foreign teachings is higher, so that they can have some psychological preparation and assist schools in educating and supervising students' mental health. Schools should pay more attention to the students, find students' problems early, seek support and help from parents, and conduct harmonious cooperation with families, solve students' problems together with parents in a timely manner to avoid irreparable consequences. Schools can call parents to communicate more with their children, provide psychological and emotional counseling for children, care for children, not to put too much pressure on children, rationally guide children in learning, etc. Schools can also strengthen the connection and communication between schools and families by holding parents' meetings, sending a letter to each student's parents every semester, establishing parental WeChat groups, and setting up the emergency communication system and the key student telephone contact system.

\section{E. Optimize the Management Team, Improve the Management System}

The schools can organize student managers to exchange and study in various Sino-foreign cooperative universities. Everyone can sit together to exchange experience, analyze problems and solve problems. The student managers can accumulate management experience through it. Schools can also hire experienced student managers of Sino-foreign cooperative education to come to the school for guidance, put forward constructive opinions, and conduct systematic and professional training for student administrators, which is beneficial to the student management work. Schools should not only focus on improving students' academic performance. Instead, they should pay attention to cultivating students' comprehensive quality and develop high-quality international talents.

\section{REFERENCES}

[1] Liang Shuqing; Li Lei. Research on the innovation of ideological and political work in the international talent cultivation system [J]. Journal of Hebei Radio and TV University, 2011. 梁树清;李否.国际化人才培 养体系下思想政治工作创新研究 $[\mathrm{J}]$. 《河北广播电视大学学报》, 2011 .

[2] CM Liu , WM Hu.Analysis of the Type of Chinaa's Cooperative Education Model. 《Key Engineering Materials》,2010,426-427:391394.

[3] Yang Yumei; Yin Xiaofei. Research on Student Management in the Sino-foreign Cooperative Education Model [J]. Business Manager, 2011. 杨昱梅; 尹晓菲.中外合作办学模式下的学生管理工作研究 [J]. 《经 营管理者》，2011.

[4] Mi Yongsheng; Shen Xu. Analysis of the Student Work in Higher Vocational Colleges under the Mode of International Cooperative Education[J]. Science and Technology Information Development and Economy, 2009. 米永胜; 沈旭国际合作办学模式下高职院校学生工 作探析[J].《科技情报开发与经济》，2009.

[5] Zhou Bilei. An Analysis of Student Management Work in Sino-foreign Cooperative Universities [J]. Journal of Changsha University, 2010. 周 碧蕾.中外合作办学学生管理工作探析[J]. 《长沙大学学报》, 2010.

[6] Ji Hongliang. Study on the Reform of Student Management in Higher Vocational Colleges [J]. SME Management and Technology (First Edition), 2015. 计宏亮. 高职院校学生管理工作改革研究 $[\mathrm{J}]$. 《中小企 业管理与科技(上旬刊)》, 2015.

[7] Xie Xuemei. Research on incentive factors and characteristics of mental health workers in universities and high schools [D]. Master thesis, Southwest University, 2008. 谢雪梅-.大中学心理健康学校社会工作 者的激励因素及特点研究[D].《西南大学硕士论文》, 2008.

[8] Ma Jiao. Research on the Status Quo and Countermeasures of Moral Education in College PE Teaching in Hubei Province [D]. Master thesis, Wuhan Sports University, 2009. 马姣.湖北省高校体育教学中德育教 育现状及对策研究[D].《武汉体育学院硕士论文》，2009. 